\title{
Peluang Usaha Kecil Kuliner Rumahan Masyarakat Perum Kharisma Koka Ditengah Pandemi Covid 19
}

\author{
Erric Kondoy ${ }^{1}$, Rahmania Rahman ${ }^{2}$ \\ ${ }^{12}$ Fakultas Ilmu Sosial, Universitas Negeri Manado \\ email: errickondoy@gmail.com.rahmania9393@gmail.com
}

\begin{abstract}
Abstrak. The policy of staying at home due to the prevention of the spread of Covid 19 is the primary of economic problems in the poor society since they were laid off by the company where they worked in and therefore, they cannot fulfill their family needs anymore. This reality force them to find solution to fulfill their family needs in which almost all society get impact of this including the Kharisma Koka residential. It encourages the people there particularly the housewives to concern with culinary business at home by selling various foods such as typical food of North Sulawesi and even some kinds of food from outside the province. Thishome culinary is regarded as the excellent business opportunity in the Covid 19 pandemic.
\end{abstract}

Key words: Kharisma Koka Residential, Home Industry, Culinary Business.

\section{PENDAHULUAN}

Virus Corona atau covid 19 adalah virus yang sedang mewabah di dunia, virus ini menyebar dengan cepat, virus ini tidak pandang bulu dalam penularanya baik masyrakat kelas bawah bahkan masyarakat kelas atas, orang kaya, orang miskin, pejabat, dan masyarakat biasa. Keadaan ini membuat kepanikan di seluruh penjuru dunia, dan menyita perhatian berbagai pihak. Akademisi, pakar ekonomi, politik, dan tokoh agama pun ikut terlibat dalam memikirkan masalah wabah ini. Virus corona jenis baru, SARS-CoV2, masih terus diteliti untuk mengetahui karakteristik virus ini dan bagaimana penularan serta penyebarannya. Namun, WHO menjadikan penularan MERS dan SARS sebagai acuan karena penyebabnya berasal dari kelompok virus yang sama, yaitu coronavirus. Penularan virus corona bisa terjadi melalui berbagai hal berikut: Droplets atau tetesan cairan yang berasal dari batuk dan bersin Kontak pribadi seperti menyentuh dan berjabat tangan Menyentuh benda atau permukaan dengan virus di atasnya, kemudian menyentuh mulut, hidung, atau mata sebelum mencuci tangan.
Pencegahan yang bisa dilakukan untuk menghambat atau menekan laju penularan virus corona, di antaranya: Menghindari kontak dekat dengan pasien penderita penyakit saluran pernapasan akut, Sering mencuci tangan dengan sabun atau menjaga kebersihannya dengan hand sanitizer berkadar alkohol minimal 70 persen. Menghindari kontak dengan peternakan atau binatang liar tanpa perlindungan Menjaga dan memperkuat imunitas tubuh Memperhatikan situasi tersebut maka pemerintah Provinsi Sulawesi Utara dalam hal ini Gubernur Olly Dondokambey. SE mengeluarkan kebijakan yang tertuang dalam kebijakan Gubernur no 97 tahun 2020 tanggal 16 Maret menetapkan status siaga darurat penanganan bencana non alam virus corona atau covid 19 di Sulut, yang mengacu kepada keputusan presiden no 7 tahun 2020 tentang gugus tugas pecepata penanganan corona virus desease 2019. Sehingga aktivitas masyarakat tergangu dengan dibatasinya kerumunan orang, dan harus menjaga jarak antara orang. Inilah yang memaksa masyarakat harus tetap tinggal dirumah, bahkan ada yang dipecat dari tempat kerja, dan harus berusaha bertahan hidup dengan cara berjualan makanan dari rumah. 
Jurnal Ilmu Sosial dan Pendidikan

http://ejournal.mandalanursa.org/index.php/JISIP/index

Terakreditasi Peringkat 5 (No. SK: 85/M/KPT/2020)

\section{TINJAUAN PUSTAKA}

Menurut Sriyana (2010) dalam bukunya bahwa acuan utama pengertian UMKM mengacu pada Undang-undang UMKM Nomor 20 tahun 2008, yaitu :

1. Usaha Mikro adalah usaha produktif milik perorangan dan atau badan usaha perorangan yang memenuhi kriteria usaha mikro.

2. Usaha kecil adalah usaha ekonomi produktif yang berdiri sendiri, yang dilakukan oleh orang perorangan atau badan usaha yang bukan merupakan anak perusahaan atau bukan cabang perusahaan yang dimiliki, dikuasai atau menjadi bagian baik langsung maupun tidak langsung dari usaha menengah atau usaha besar yang memenuhi kriteria usaha kecil.

3. Usaha menengah adalah usaha ekonomi produktif yang berdiri sendiri, yang dilakukan oleh orang perorangan atau badan usaha yang bukan merupakan anak perusahaan atau cabang perusahaan yang dimiliki, dikuasai aau menjadi bagian baik langsung maupun tidak langsung dengan usaha kecil atau usaha besar dengan julah kekayaan bersih atau hasil penjualan tahunan sebagaimana diatur dalam undangundang ini.

4. Usaha besar adalah usaha ekonomi produktif yang dilakukan oleh badan usaha dengan jumlah kekayaan bersih atau hasil penjulan tahunan lebih besar dari usaha menengah, yang meliputi usaha nasional milik Negara atau swasta, usaha patungan dan usaha asing yang melakukan kegiatan ekonomi di Indonesia.

\section{METODE PENELITIAN}

Penelitian ini menggunakan jenis penelitian kualitatif, penelitian yang menceritakan fakta-fakta mengenai peluang usaha kuliner masyarakat perum Kharisma Koka ditengah pandemi covid 19. Penelitian kualitatif adalah penelitian yang mendeskripsikan dan menganalisis makna yang terkandung dibaliknya fenomena sebagai
Vol. 4. No. 3 Juli 2020

p-ISSN: 2598-9944 e-ISSN: 2656-6753 makna yang tersembunyi, atau dengan sengaja disembunyikan sehingga menghasilkan data deskriptif dalam bentuk kata-kata, baik tertulis maupun lisan (Sugioyono, 2017)

Penelitian ini bertujuan untuk melihat atau mengetahui peluang usaha kuliner rumahan meskipun berada di tengah pandemi covid 19. Fokus penelitian ini dilakukan untuk melihat seberapa besar peluang usaha kuliner rumahan bagi warga perumahan Kharisma dengah pandemi covid 19. Perumahan Kharisma ditentukan sebagai tempat pengumpulan data.

Teknik pengumpulan data dilakukan dengan metode pengamatan (observasi) merupakan metode pengumpulan data yang digunakan untuk mengumpulkan data melalui pengamatan, wawancara (interview) dilakukan untuk mengali informasi dan dilakukan secara bebas, dan dokumentasi merupakan pengumpulan data melalui pengambilan gambar di lokasi berupa dokumen atau foto.

Proses analisis dalam penelitian kualitatif, secara khusus dilakukan secara induktif, interaksi dari setiap unit datanya, bersamaan dengan proses pelaksanaan pengumpulan data, dan dengan proses siklus (Miles \& Huberman, 2014). Empat komponen utama analisis tersebut adalah pengumpulan data, reduksi data, sajian data, penarikan kesimpulan. Menguji keabsahan data penelitian menggunakan metode Trianggulasi, yaitu pemeriksaan keabsahan data yang memanfaatkan sesuatu yang lain di luar data untuk keperluan pengecekan atau sebagai pembanding terhadap data tersebut, dan teknik trianggulasi yang paling banyak digunakan adalah dengan pemeriksaan melalui sumber yang lainnya.

\section{PEMBAHASAN}

Kota Manado yang notabene merupakan ibu kota Provinsi Sulut yang juga merupakan pusat ekonomi dan bisnis Sulut paling banyak merasakan dampaknya, hal ini terlihat dari di tutupnya mall-mall besar di Manado yang di dalamnya banyak terdapat banyak outlet, dan 
Jurnal Ilmu Sosial dan Pendidikan

http://ejournal.mandalanursa.org/index.php/JISIP/index

Terakreditasi Peringkat 5 (No. SK: 85/M/KPT/2020)

banyak pekerja, yang terpaksa dirumahkan, bukan hanya usaha dengan modal besar yang merasakan dampaknya tapi juga usaha dengan modal kecil atau yang pas-pasan. Banyak karyawan yang dirumahkan, atau diberhentikan dari pekerjaannya, banyak Rumah makan yang ditutup, ataupun kalau tetap buka penghasilanya menurun drastis, dikarenakan masyarakat yang sudah takut beraktivitas di luar rumah menggikuti anjuran pemerintah stay at home. Situasi ini sangat berdampak pada segi ekonomi semua golongan masyarakat baik yang berprofesi sebagai Aparatur Sipil Negara (ASN) maupun Swasta (kantoran/toko), bahkan masyarakat yang memiliki profesi dengan pendapatan harian seperti buruh bangunan dan pedagang baik keliling atau usaha rumah makan. Ini memaksa masyarakat harus memutar otak untuk tetap menunjang perekonomian keluarga. Hal ini juga ikut dirasakan masyarakat yang tinggal dilingkungan perumahan Kharisma Koka yang meskipun lokasi perumahan ini sudah berada di wilayah Minahasa akan tetapi warga perumahan masih banyak yang memegang KTP warga kota Manado, dan banyak yang bekerja di wilyah kota Manado sehingga efek wabah Corona di Manado masih sangat dirasakan warga perum. Sehingga memaksa warga untuk memutar otak lebih keras lagi agar supaya kebutuhan keluarga bisa terpenuhi sebagai efek dirumahkan. Hal inilah yang mendorong hampir sebagian warga terutama ibu-ibu menjalankan usaha kuliner dari rumah, dengan berjualan banyak sekali jenis kuliner, mulai dari kue-kue khas Sulawesi Utara, makanan- makanan khas Sulawesi Utara, bahkan kue-kue dan makanan-makanan khas dari luar Sulawesi Utara juga ikut di jual. Hal ini terlihat dari beberapa group whats up warga perum yang begitu ramai dengan berbagai macam dagangan. Usaha kuliner rumahan di pandang warga adalah jenis usaha yang memiliki peluang di tengah pandemi Covid 19.

Sesuai pengamatan penulis yang juga sebagai warga perum fenomena usaha kuliner rumahan sudah banyak dilakukan, sehingga
Vol. 4. No. 3 Juli 2020

p-ISSN: 2598-9944 e-ISSN: 2656-6753

warga perum tidak lagi kesulitan mencari makan diluar, karna hampir semua jenis makanan telah tersedia.

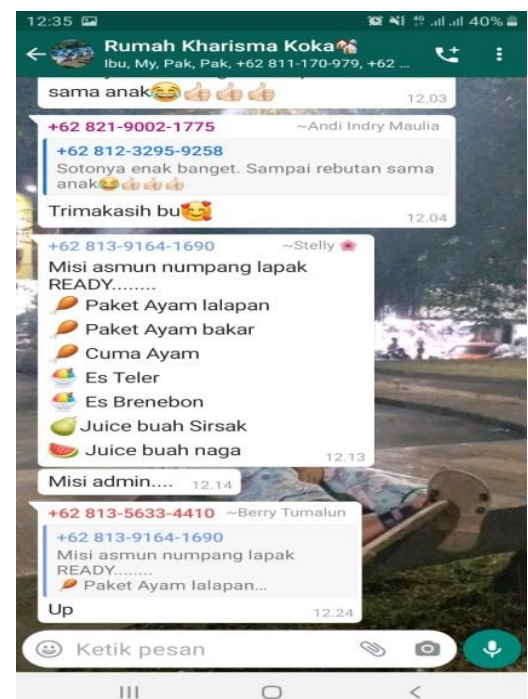

Gambar 4.1 : kuliner yang di jual lewat whats up

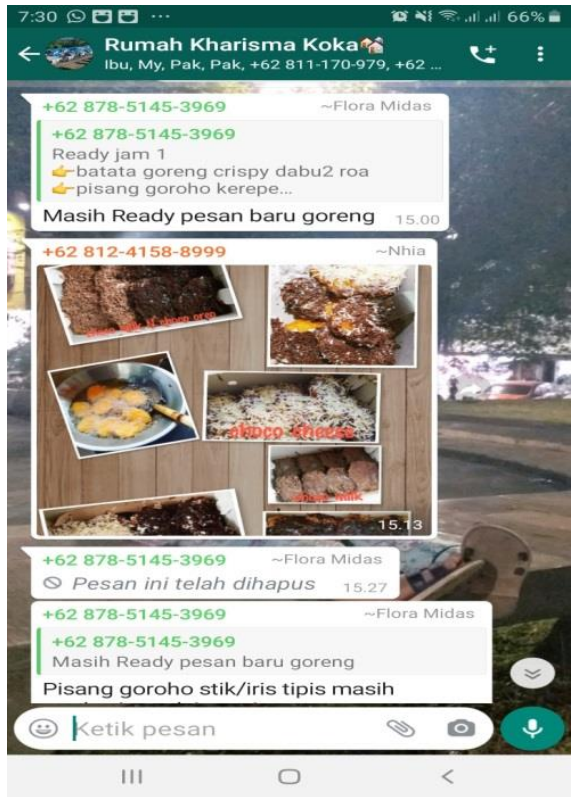

Gambar 4.2 : kuliner yang di jual lewat whats up

Dampak bejualan dari rumah sangat di rasakan masyarakat yang ada di kompleks perumahan baik produsen maupun sebagai konsumen. Bagi produsen hasil dari penjualan ini sangat membantu ekonomi keluarga mereka ditengah wabah covid 19 ini, baik untuk kebutuhan sehari-hari, dan angsuran-angsuran 
,yang harus dibayarkan yang sudah terlanjur di ambil sebelum wabah ini. Salah satunya warga perumahan yang bernama ibu Debby mengatakan berjualan dari rumah sangat membantu ekonomi keluarga mereka setelah suaminya di rumahkan sedangkan mereka harus membayar angsuran rumah, biaya sekolah anak-anak, dan kebutuhan lainya. Sedangkan seorang warga yang bernama Gebby sebagai konsumen merasa sangat terbantu dengan adanya warga-warga yang berjualan dari rumah, selain tidak perlu jauh-jauh mencari makanan diluar kompleks perumahan, dia juga tidak perlu takut dengan higienisnya makanan yang tidak jelas diluar perumah yang mungkin telah terkena virus covid 19.

\section{PENUTUP}

Hasil penelitian dan pengamatan usaha kuliner rumahan yang di jalankan masyarakat perum Kharisma sangat membantu masyarakat ditengah pandemi covid 19, yang mengharuskan masyarakat bekerja atau beraktivitas dirumah saja. Baik penjual dalam memenuhi kebutuhan hidup, dan kebutuhan yang lain ditengah krisis covid 19. Begitu juga bagi pembeli merasa sangat terbantu dengan adanya masyarakat yang berjualan makanan dikompleks, dan juga bisa saling membantu di masa sulit ini.

\section{DAFTAR PUSTAKA}

bbc.com, diakses 29 Juni 2020 pukul 17.52 Corona.sulutprov.go.id diakses 14 Juni, pukul 21.15

Peraturan.bpk.go.id/home/details/134544/kepre s no 7 tahun 2020, diakses 14 Juni 2020, pukul 21.15

Miles, M. B. \& Huberman, M. B., 2014.Analisis Data Kualitatif : Buku Sumber Tentang Metode-metode Baru. Jakarta: UI-Press

Sriyana, J.2010, Strategi Pengembangan Usaha Kecil Dan Menengah (UKM): Studi Kasus Di Kabupaten Bantul, paper, Simposium Nasional 2010 : Menuju Purworejo Dinamis dan Kreatif. Artikel.
Fakultas Ekonomi Universitas Islam Indonesia, Yogyakarta.

Sugioyono, 2017. Metode Penelitian Kuantitatif, Kualitatif dan R\&D. Bandung: Alfabeta.

https://www.kompas.com/tren/read/2020/03/19/ 064600465/cara-penularan-virus-coronadan-alasan-pentingnya-social-distancing, diakses 29 Juni 2020, pukul 17.05

https://www.scribd.com/doc/206984637/Strateg iPengembangan-Usaha-Kecil-Dan-

Menengah. . Hal. 79-104. Diakses 29 Juni 2020, pukul 21.30 